\section{PP-601 前立腺癌新規分子マーカーの探索}

\section{高知大学医学部泌尿器科学"), 高知大学医学部腫瘍病理学 ${ }^{2)}$} 佐竹 宏文 ${ }^{12}$, 蘆田 真吾 ${ }^{1)}$, 降幡 睦夫 ${ }^{2}$, 執印 太郎 ${ }^{1)}$ 前立腺癌の診断・治療において前立腺特異抗原（PSA）は 有用であり、早期発見・治療による予後改善に貢献してい る。しかし、幾つかの問題点が指摘されている。PSA は悪 性度 (Gleason grade) や進行度、予後とは必ずしも相関し ない。また、PSA 低値でも非常に Gleason grade が高く、 進行性の癌が見つかる場合があり、今日、進行度や悪性度 を正確に反映し、予後を予測できるような新しい腫瘍マー カーの開発が期待されている。そこで、我々は cDNA マイ クロアレイと Laser Microdissection 法を用いて、未治療進 行性前立腺癌 12 症例における遺伝子発現プロファイルの 解析を行い、前立腺癌新規分子マーカーの探索を試みた。 $50 \%$ 以上の症例で 5 倍以上の発現上昇を認めるものとし て、AMACR など過去に前立腺癌との関連性を報告されて いるものを含む 354 個の遺伝子が抽出された。その中で分 泌蛋白をコードするものが 17 遺伝子認められ、それらを新 規前立腺癌分子マーカー解析の候補とした。これらの遺伝 子について発現解析等を行い、分子マーカーとしての有用 性について検討を行ったので報告する。

\section{PP-603 新規前立腺癌マーカータンパク質 TT 902 の組織学的発現解析}

\section{慈恵医大医学部泌尿器科学 ${ }^{11}$, 慈恵医大医学部病理学講座 ${ }^{2}$}

車 英俊 ${ }^{1)}$, 鎌田 裕子 ${ }^{11}$, 木村 高弘 ${ }^{11}$, 柚須 恒 ${ }^{12}$,

鷹橋 浩幸 ${ }^{2}$, 下村 達也 ${ }^{12}$, 山田 裕紀 ${ }^{1)}$, 佐々木 裕 ${ }^{1}$,

山崎 春城 ${ }^{1}$, 頴川 晋1)

【目的】高分子プロテオミクスによって発見した新規前立腺 癌バイオマーカーTT902の臨床的有用性を手術検体の免 疫組織染色により検討した。方法】TT902のアミノ酸シー クエンス結果よりペプチド抗体を作成した。この抗体を用 いて、東京慈恵医大泌尿器科で摘除された 64 例の前立腺全 摘標本の免疫組織染色を行い、癌部、PIN 部、Hyperplasia 部、正常腺上皮部での染色強度を 4 段階でスコア化した。 【結果】TT902はほぼすべての前立腺癌部で発現がみられ た。癌とPIN、癌と hyperplasia、癌と正常腺上皮ではいず れも癌で有意に発現強度が高かった（いずれも $\mathrm{p}<0.001) 。$ Hyperplasia と正常腺上皮ではTT902 の発現に差は見ら れなかった。また、TT902の発現強度は、Gleason grade、 stage、血清 PSA 值とはいずれも関連は見られなかった。既 存のマーカーである AMACR (P504S) と比較したところ、 TT902 陽性、AMACR 陰性の癌組織や、TT902 陰性、 AMACR 陽性の癌組織も散見された。結語】新規前立腺癌 マーカーTT902の臨床的に非常に有用であると考えられ る。機能解析や血清での発現等の更なる検討を要する。

\section{PP-604 群馬県における前立腺がん検診の 14 年 間の集計一年度別、PSA 值別、スクリー ニング方法及び検診受診回数別の臨床病 期一}

\section{群馬大学大学院医学系研究科器官代謝制御学泌尿器病態学 群馬大学グループ泌尿器腫瘍研究会}

河野 真意, 伊藤 一人, 山本 巧, 武智 浩之, 大井 勝, 久保田 裕, 鈴木 和浩

【目的】群馬県において前立腺がん検診に PSA 検查を導入 した 1992 年から 2005 年までに発見された前立腺がんの臨 床病期を年度別、PSA 值別、スクリーニング方法及び検診 受診回数別に解析した。【対象】14 年間ののべ検診受診者は 112,510 人で 1,313 人 $(1.2 \%)$ に前立腺がんが発見された。 【結果】年度別では、1992 年に全体の $50 \%$ であった T1c/T 2 症例が 2004 年に $68 \%$ に増加、一方 T4/N1/M1 症例は $16 \%$ から $6 \%$ に減少していた。スクリーニング方法別で は、年齢別 PSA 基準值導入後、 $71 \%$ が $\mathrm{T} 1 \mathrm{c} / \mathrm{T} 2$ 症例となっ た。検診受診回数別では、T1c/T2 症例の割合が初回検診受 診者で $64 \%$ に対し複数回検診受診者では $74 \sim 88 \%$ と高 かった。T4/N1/M1 症例が初回検診受診者 $7.7 \%$ で、以降受 診回数とともに減少した。考察】前立腺癌検診の普及と精 度向上により、今後、本邦に打ける検診発見がんの臨床病 期はより早期へシフトすると予想され、欧米先進諸国のよ うな死亡率低下が期待される。 前立腺癌の予後因子となりうると考えられた。 